\title{
GAMBARAN RASIONALITAS PENGGUNAAN ZINC DAN PROBIOTIK PADA PASIEN DIARE
} PEDIATRIK

\section{RATIONALITY DESCRIPTION OF ZINC AND PROBIOTIC USE IN PATIENTS OF PEDIATRIC DIARRHEA}

\author{
Suci Fitriani Sammulia ${ }^{1 *}$, Suhatri ${ }^{2}$, Susi Safitri ${ }^{1}$ \\ ${ }^{1}$ Institut Kesehatan Mitra Bunda, Prodi Sarjana Farmasi, Kota Batam \\ ${ }^{2}$ Universitas Andalas, Fakultas Farmasi, Padang
}

Naskah diterima tanggal 28 Maret 2020

\begin{abstract}
Diarrhoea is still one of the leading causes of pain and death in the world. Diarrhoea attacks almost all ages and is mostly experienced by children under five years old or toddlers. Management of acute diarrhoea in children according to the World Gastroenterology Organization consists of oral rehydration therapy, zinc supplement therapy, diet, probiotics, and antibiotics. This study aims to determine the description of the use of zinc and probiotics in pediatric diarrhoea patients who were treated at Hospital X in Batam City for the period 2017-2018. This research was conducted retrospectively, data obtained from the patient's medical record. Samples were taken as many as 61 medical records with purposive sampling. The results showed that diarrhoea sufferers were dominated by male sex (33 patients) compared to women (28 patients) with the highest incidence in the age range of 1 month-12 month ie (23 patients). The rationality percentage of zinc use is $67.21 \%$ and irrational is $32.79 \%$. Meanwhile, the percentage of the rationality of the use of probiotics is $59.01 \%$ and irrational is $40.98 \%$
\end{abstract}

Keywords : Diarrhea, Pediatric Patients, Rationality, Zinc and Probiotics

\begin{abstract}
ABSTRAK
Penyakit diare sampai saat ini masih menjadi salah satu penyebab utama kesakitan dan kematian terbesar di dunia. Diare menyerang hampir seluruh usia, dan kebanyakan dialami oleh anak berusia di bawah lima tahun atau balita. Penatalaksanaan diare akut anak menurut World Gastroenterology Organisation terdiri dari terapi rehidrasi oral, terapi suplemen zinc, diet, probiotik, dan antibiotik. Penelitian ini bertujuan untuk mengetahui gambaran penggunaan zinc dan probiotik pada pasien diare pediatrik yang dirawat di Rumah Sakit X Kota Batam periode 2017-2018. Penelitian ini dilakukan secara deskriptif retrospektif, data diperoleh dari rekam medik pasien. Sampel diambil sebanyak 61 rekam medik dengan purposive sampling. Hasil penelitian menunjukkan bahwa penderita diare didominasi oleh jenis kelamin laki-laki (33 pasien) dibanding perempuan (28 pasien) dengan kejadian tertinggi pada rentang usia 1 bulan- 12 bulan yakni (23 pasien). Persentase rasionalitas penggunaan zinc yaitu sebesar $67,21 \%$ dan tidak rasional sebesar $32,79 \%$. Sementara itu, persentase rasionalitas penggunaan probiotik adalah sebesar $59,01 \%$ dan tidak rasional sebesar $40,98 \%$
\end{abstract}

Kata K!nnci : Diare, Pasien Pediatrik, Rasionalitas, Zinc dan Probiotik

\section{PENDAHULUAN}

Penyakit diare masih menjadi salah satu penyebab utama kesakitan dan kematian terbesar di dunia sampai saat ini. Diare menyerang hampir seluruh usia, dan kebanyakan dialami oleh anak berusia di bawah lima tahun atau balita (Iskandar, 2015).

Penyebab utama kematian akibat diare

Alamat korespondensi :

sucifitriani.sammulia22@gmail.com adalah tatalaksana yang tidak tepat baik di rumah maupun di sarana kesehatan. Untuk menurunkan kematian akibat diare perlu tatalaksana yang cepat dan tepat (Buletin Jendela Data Informasi Kemenkes RI 2011).

Data Profil Kesehatan Kota Batam tahun 2015 menyatakan bahwa penyakit diare dan gastroentritis menempati posisi keempat pada sepuluh penyakit terbesar kunjungan pasien di puskesmas se-Kota Batam tahun 2015 dengan jumlah yakni sebesar 7.153 kasus. 
Penatalaksanaan diare akut anak menurut World Gastroenterology Organisation (2012) terdiri dari terapi rehidrasi oral, terapi suplemen zinc, diet, probiotik, dan antibiotik. Studi WGO menyebutkan bahwa penggunaan zinc dan probiotik dapat mengurangi keparahan dan lamanya diare akut pada anak.

Studi World Health Organisation (WHO) membuktikan bahwa pemberian zinc kepada penderita diare dapat mengurangi prevalensi diare sebesar $34 \%$, mengurangi jangka waktu diare akut sebesar 20\%, mengurangi jangka waku diare persisten sebesar $24 \%$ dan dapat mencegah kegagalan terapi atau kematian akibat terapi diare persisten sebesar 42\% (Depkes RI, 2011).

Berdasarkan tingginya angka prevalensi diare anak di Kota Batam serta belum pernah dilakukannya penelitian tentang gambaran penggunaan zinc dan probiotik dalam penanganan diare anak di Rumah Sakit X Kota Batam, maka perlu dilakukan penelitian untuk mengetahui rasionalitas pemberian zinc dan probiotik pada pasien diare anak di Rumah Sakit X Kota Batam.

\section{METODE PENELITIAN}

Penelitian ini merupakan penelitian deskriptif non-eksperimental, dengan pengambilan data secara retrospektif melalui penelusuran pada data rekam medik pasien pediatrik yang terdiagnosis diare. Populasi yang digunakan dalam penelitian ini adalah seluruh pasien anak yang datang berobat di Rumah Sakit $X$ Kota Batam dan didiagnosa diare baik diare spesifik maupun non spesifik. Kriteria Inklusi dalam penelitian ini adalah rekam medik pasien balita yang didiagnosa diare yang mendapatkan terapi zinc dan probiotik serta berobat di Rumah Sakit X pada tahun 2017-2018, rekam medik pasien yang dapat terbaca dengan jelas. Kriteria eksklusi adalah rekam medik pasien dengan penyakit lain yang perlu pengawasan dan pengobatan khusus, dalam kondisi atau diduga mengidap gangguan respon imun sehingga kurang mampu mengatasi infeksi, dan anak dengan gizi buruk dan pasien diare pediatrik yang pulang paksa atau meninggal sebelum terapi selesai. Besar sampel dihitung menggunakan rumus Taro Yamane \& Slovin :

$$
\mathrm{n}=\frac{\mathrm{N}}{\mathrm{N} \mathrm{d}^{2}+1}
$$

Ket:

$\mathrm{N}=$ Jumlah populasi

$\mathrm{n}=$ Jumlah sampel

$d^{2}=$ Presisi (ditetapkan 10\% dengan tingkat kepercayaan 95\%)

Bahan yang digunakan adalah rekam medik pasien balita yang didiagnosa diare dan diberikan probiotik dan zink. Data dikumpulkan dengan cara melihat data resep dan data rekam medis pasien balita yang didiagnosa diare kemudian data disesuaikan dengan pola pengobatan yang rasional sesuai dengan modul penggunaan obat rasional dari WGO (2012) dan WHO (2009).

\section{Analisis Data}

Analisis data yang dilakukan menggunakan analisis data univariat untuk mendapatkan gambaran distribusi dalam bentuk tabel distribusi frekuensi dengan jumlah dan ukuran persentase masing- masing kelompok. Data yang dianalisa antara lain distribusi ketepatan indikasi obat, ketepatan pemilihan obat, ketepatan dosis, ketepatan cara pemberian obat dan ketepatan lama pemberian obat.

\section{HASIL DAN PEMBAHASAN Karakteristik Pasien}

Sampel yang di ambil dari tahun 20172018 di Rumah Sakit X Kota Batam adalah rekam medis pasien anak yang didiagnosa diare baik spesifik maupun nonspesifik sebanyak 61 rekam medis. Karakteristik pasien diare pediatrik di Instalasi Rawat Inap Rumah Sakit X periode tahun 2017 dan 2018 dikategorikan berdasarkan jenis kelamin, usia, jenis diare dan gejala atau keluhan diare tercantum dalam Tabel 1.

Pasien diare pediatrik di Instalasi Rawat Inap Rumah Sakit X Kota Batam periode tahun

Tabel 1. Demografi Pasien Diare Anak di Instalasi Rawat Inap Rumah Sakit X Kota Batam

\begin{tabular}{|c|c|c|c|c|}
\hline \multirow[t]{2}{*}{ Usia } & \multicolumn{2}{|c|}{ Jen is Kelamin } & \multirow{2}{*}{$\begin{array}{l}\text { Jumlah } \\
\text { Pasien }\end{array}$} & \multirow{2}{*}{$\begin{array}{c}\% \\
(n=61)\end{array}$} \\
\hline & Laki-laki & Perempuan & & \\
\hline${ }^{*}$ Neonatus (0-28hari) & 0 & 0 & 0 & $0 \%$ \\
\hline Bayi (1-12 bulan) & 13 & 10 & 23 & $37,71 \%$ \\
\hline Balita (1-3 tahun) & 6 & 11 & 17 & $27,87 \%$ \\
\hline Anak-anak (3-5 tahun) & 5 & 5 & 10 & $16,39 \%$ \\
\hline${ }^{* * K a n a k-k a n a k ~(5-11 ~ t a h u n) ~}$ & 9 & 2 & 11 & $18,03 \%$ \\
\hline Jumlah & 33 & 28 & 61 & $100 \%$ \\
\hline
\end{tabular}

${ }^{*}$ Menurut Taketomo, 2009

${ }^{* *}$ Menurut Depkes RI, 2011 
Tabel 2. Persentase Parameter Tepat Indikasi dan Tepat Pasien pada Pasien Diare Anak di Instalasi Rawat Inap RS. X

\begin{tabular}{cccc}
\hline Ketepatan & Probiotik & Zinc & Persentase $(\mathrm{n}=61)$ \\
\hline Indikasi dan Pasien & 53 & 53 & $86,89 \%$ \\
\hline Diare Akut Spesifik & 8 & 8 & $13,11 \%$ \\
Diare Akut Non-spesifik & 61 & 61 & $100 \%$ \\
\hline Jumlah & & & \\
\hline
\end{tabular}

2017 dan 2018 didominasi oleh pasien berjenis kelamin laki-laki sebanyak $33(54,09 \%)$ pasien dan perembuan 28 orang (45,90\%). Adanya perbedaan jenis kelamin tidak menjadi faktor penyebab timbulnya diare, karena anak laki-laki dan perempuan memeiliki resiko yang sama terkena diare (Indriani, et.al, 2019).

Data distribusi pasien berdasarkan usia menunjukkan bahwa dari 61 kasus diare pada anak, kelompok usia dengan persentase tertinggi adalah kelompok usia bayi yaitu 1 bulan sampai 12 bulan sebanyak 23 pasien $(37,71 \%)$. Anak terkena diare pada usia ini dapat disebabkan karena memiliki system immun yang masih lemah. faktor imunodefisiensi pada masingmasing anak yaitu apabila daya tahan tubuh balita baik maka tubuh dapat menahan patogen/kuman yang masuk kedalam tubuh, sedangkan apabila daya tahan tubuh balita menurun maka tubuh tidak dapat menahan patogen/kuman yang masuk kedalam tubuh (Sukardi, 2016). Selain itu secara fisiologis sistem pencernaan balita yang belum cukup matur (organ-organnya belum matang), sehingga rentan terkena penyakit saluran pencernaan. Serta dapat disebabkan masalah kebersihan makanan termasuk kebersihan botol susu (Hikmawati, 2012)

\section{Rasionalitas Pengobatan}

Rasionalitas pengobatan diare pada anak pada penelitian ini dilakukan pada 61 data rekam medik di RS.X Kota Batam pada periode 20172018. Kriteria Rasionalitas pengobatan pada penelitian inia adalah tepat indikasi,tepat pasien, tepat obat dan tepat dosis.

\section{Tepat indikasi}

Tepat indikasi adalah ketepatan memutuskan pemberian obat yang sepenuhnya berdasarkan alasan medis dan terapi farmakologi benar-benar diperlukan (Tidak ada respon terhadap modifikasi gaya hidup) (Sumawa et al.
2015).

Gambaran pengobatan yang dikategorikan tepat indikasi dilihat dari perlu tidaknya pasien diberikan zinc atau probiotik berdasarkan kondisi pasien. Berdasarkan hasil penelitian dari 61 rekam medik pasien anak diare yang tepat indikasi pemberian zinc dan probiotic adalah $100 \%$. Penelitian ini sejalan dengan penelitian yang di lakukan oleh Indriani et al (2019) dan Hardiansyah et al. (2018).

Pengunaan zinc dan probiotik dikategorikan tepat indikasi jika obat yang diberikan sesuai dengan diagnosa kondisi diare pasien selama di rawat di instalasi rawat inap RS.X dari tahun 2017-2018. Selama anak diare, terjadi peningkatan hilangnya cairan dan elekrolit (natrium, kalium dan bikarbonat) yang terkandung dalam tinja cair anak. Derajat dehidrasi diklasifikasikan sesuai dengan gejala dan tanda yang mencerminkan jumlah cairan yang hilang. Rejimen rehidrasi di pilih sesuai dengan derajat dehidrasi.

Zinc merupakan mikronutrien penting untuk kesehatan dan perkembangan anak. Zinc hilang dalam jumlah banyak dalam diare. Penggantian zinc yang hilang ini penting untuk membantu kesembuhan anak dan menjaga anak tetap sehat di bulan-bulan berikutnya. Telah dibuktikan bahwa pemberian zinc selama periode diare, mengurangi lamanya dan tingkat keparahan episode diare dan menurunkan kejadian diare pada 2-3 bulan berikutnya. Berdasarkan bukti ini, semua anak dengan diare harus diberi zinc, segera setelah anak tidak muntah (WHO, 2009).

Probiotik berfungsi untuk mengurangi keparahan dan lamanya diare akut pada anak (WGO, 2012), sehingga pemberian probiotik pada anakyang terkena diare dinyatakan tepat indikasi. Persentase tepat indikasi pada pasien diare pediatrik dapat dilihat pada Tabel 2.

Tabel 3. Persentase Parameter Tepat Obat pada Pasien Diare Anak di Instalasi Rawat Inap RS.X

\begin{tabular}{cccc}
\hline Ketepatan Obat & Jenis Obat & Jumlah Kasus & $\begin{array}{c}\text { Persentase } \\
(\mathrm{n}=61)\end{array}$ \\
\hline $\begin{array}{c}\text { Suplemen Zinc } \\
\text { Probiotik }\end{array}$ & Zinc & 61 & $100 \%$ \\
\hline
\end{tabular}


Tabel 4. Ketepatan Dosis Suplemen Zinc yang Diberikan pada Pasien diare Anak di Instalasi Rawat Inap RS.X

\begin{tabular}{ccccc}
\hline $\begin{array}{c}\text { Evaluasi } \\
\text { Ketepatan }\end{array}$ & $\begin{array}{c}\text { Nama } \\
\text { Obat }\end{array}$ & $\begin{array}{c}\text { Jumlah } \\
\text { Kasus }\end{array}$ & Dosis resep & Dosis Standar* \\
\hline Tepat Dosis & & 41 & $<6$ bulan= $10 \mathrm{mg} /$ hari & \\
& Zinc & 0 & $>6$ bulan $=20 \mathrm{mg} /$ hari & $<6$ bulan=10 mg/hari \\
Dosis Lebih & & 20 & $>6$ bulan $=20 \mathrm{mg} /$ hari & $>6$ bulan= $20 \mathrm{mg} / \mathrm{hari}$ \\
Dosis Kurang & & $2010 \mathrm{mg} /$ hari & \\
\hline
\end{tabular}

\section{Tepat pasien}

Tepat pasien ialah ketepatan pemilihan obat yang mempertimbangkan keadaan pasien sehingga tidak menimbulkan kontraindikasi kepada pasien secara individu. Evaluasi ketepatan pasien pada penggunaan zink dan prebiotik dilakukan dengan membandingkan kontraindikasi obat yang diberikan dengan kondisi pasien pada data rekam medik. (Sumawa et al. 2015)

Berdasarkan penelitian 61 rekam medik pasien anak diaredi RS. X tahun 2017-2018 dinilai tepat pasien $100 \%$ karena pemberian prebiotik dan zinksesuai dengan keadaan patologi pasien tidak menimbulkan kontra indikasi pada pasien. Tepat pasien anak diare dalam penggunaan probiotik dan zink dapat dilihat pada Tabel 2. Penelitian ini sejalan dengan penelitian yang dilakukan dengan Indriani et al (2019) dan Hardiansyah et al. (2018) dimana tepat pasien sebanyak $100 \%$

\section{Tepat Obat}

Tepat obat adalah pemberian jenis obat yang dipilih berdasarkan pertimbangan manfaat dan resiko (Sumawa et al. 2015). Evaluasi ketepatan obat dinilai berdasarkan kesesuaian pemilihan obat dengan mempertimbangkan diagnosis yang tertulis dalam rekam medik dan dibandingkan dengan standar WHO dan WGO dalam penanganan diare pada anak.

Pemberian zink dan prebiotik pada 61 pasien diare anak di RS. X tahun 2017-2018 dikategorikan tepat obat $100 \%$. Zinc sangat direkomendasikan untuk pengobatan diare karena terbukti bahwa pemberian zink dapat menurunkan tingkat keparahan dan durasi diare, serta menurunkan kemungkinan munculnya kembali diare pada 2-3 bulan setelahnya (WHO, 2009). Selain itu zink dapat mengurangi keparahan diare dan mempercepat kesembuhan diare (WGO, 2012)

Pada pemberian prebiotik menurut World gastroenterology organization (2012) pemberian probiotik aman dan efektif untuk anak terkena diare

\section{Tepat Dosis}

Tepat dosis adalah tepat dalam frekuensi pemberian, dosis yang diberikan dan jalur pemberian obat kepada pasien. Bila peresepan zink dan prebiotik berada pada rentang dosis minimal dan dosis per hari yang dianjurkan maka peresepan dikatakan tepat dosis.

Tabel 5. Ketepatan Dosis Probiotik yang Diberikan pada Pasien Diare Anak di Instalasi Rawat Inap RS.X

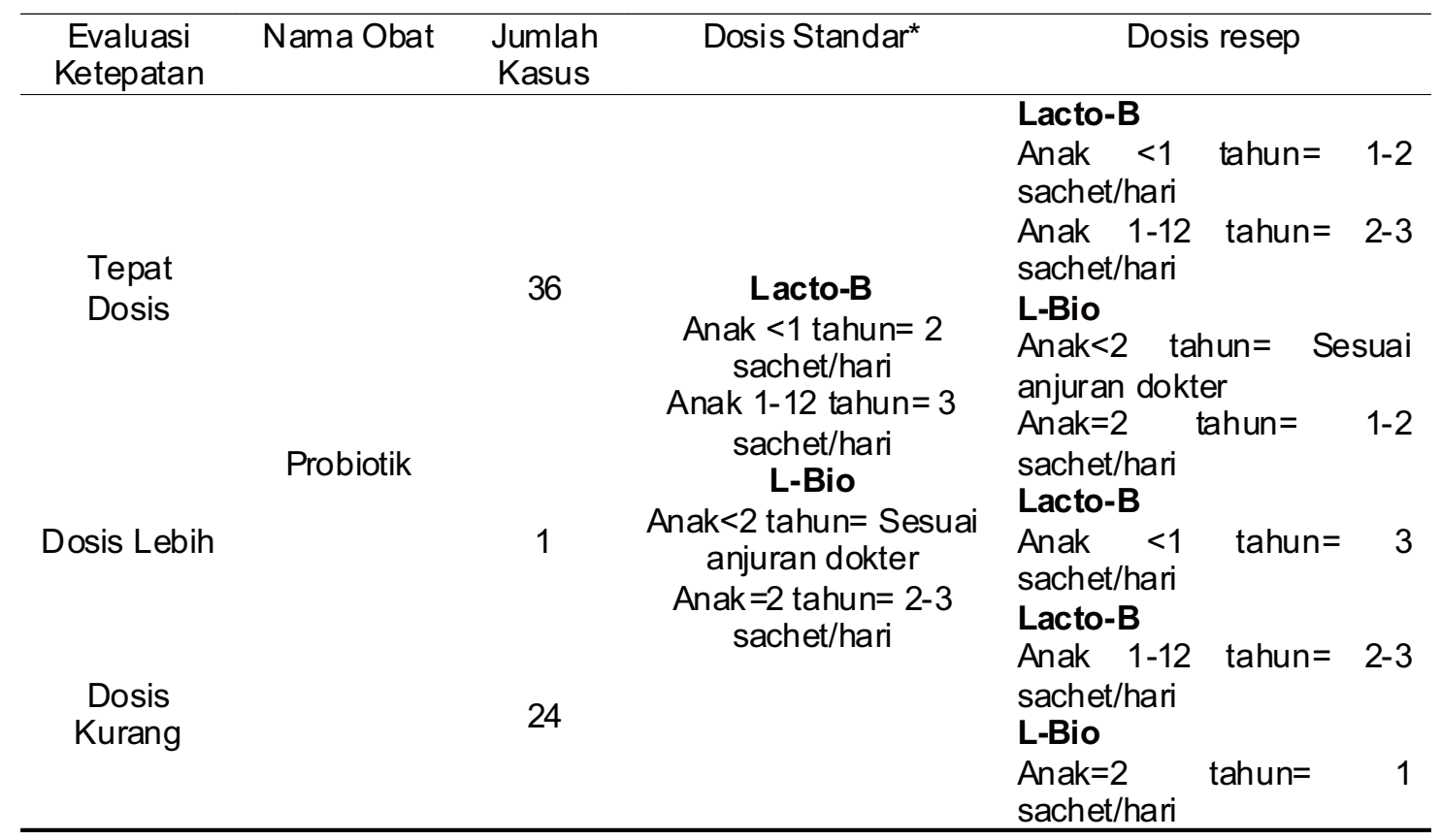


Berdasarkan hasil penelitian yang telah dilakukan terhadap pemberian zink pada pasien diare anak di RS.X tahun 2017-2018 terdapat 41 rekam medik pasien diare anak yang tepat dosis, sedangkan 20 kasus lainnya dikatakan tidak tepat dosis. Ketidak tepatan dosis pada penelitian ini adalah dosis kurang atau frekuensi pemberian kurang menurut WGO (2012). Pemberian zink dan prebiotik yang tidak tepat didasarkan pada perhitungan dosis terhadap usia.

Dikatakan dosis kurang atau dosis terlalu rendah adalah apabila dosis yang diterima pasien berada dibawah rentang dosis terapi yang seharusnya diterima pasien, dosis yang terlalu rendah dapat menyebabkan kadar obat dalam darah berada dibawah kisaran terapi sehingga tidak dapat memberikan respon yang diharapkan, sebaliknya dosis obat yang terlalu tinggi dapat menyebabkan kadar obat dalam darah melebihi kisaran terapi menyebabkan keadaan toksisitas (Cipolle dkk., 1998)

Pada pemberian prebiotik pasien diare anak di RS.X tahun 2017-2018 terdapat 36 $(59,02 \%)$ rekam medik pasien diare anak yang dikategorikan sebagai tepat dosis sedangkan 25 $(40,98 \%)$ lainnya terbagi menjadi dua kategori tidak tepat dosis. Ketidaktepatan dosis dalam penelitian ini merupakan dosis atau frekuensi yang diberikan melebihi atau kurang dari dosis standar menurut pedoman World Gastoenterology Organisation (2012). Rekam medik pasien diare anak yang dikategorikan dosis kurang adalah 24(39,34\%), sedangkan dosis berlebih adalah $1(1,64 \%)$. Pemberian probiotik dengan dosis kurang juga dapat menyebabkan terapi tidak optimal sehingga proses penyembuhan diare lebih lama, sedangkan menurut Marianti (2018)

Penelitian ini berbeda dari penelitian yang dilakukan oleh Hardiansyah et al. (2018) dimana ketepatan dosis sebesar $87 \%$, jauh lebih besar, dan penelitian Indriani et al (2019) dimana hasil penelitiannya memperlihatkan ketepatan dosis pada pasien anak adalah sebesar $91,73 \%$.

Penggunaan obat diare yang tidak rasional dapat menimbulkan dampak negatif diantaranya terjadi efek samping maupun toksisitas, terjadinya pemborosan biaya, dan tidak tercapainya manfaat klinik yang optimal dalam hal pengobatan dan kontrol penyakit diare (Kemenkes RI, 2011). Penggunaan obat dikatakan rasional apabila memenuhi kriteria tepat diagnosis, tepat indikasi penyakit, tepat pemilihan obat, tepat dosis, tepat penilaian kondisi pasien dan waspada terhadap efek samping. Sedangkan dikatakan tidak rasional apabila diberikan dengan tidak memenuhi kriteria ketepatan tersebut. (Kemenkes RI, 2011).

\section{KESIMPULAN}

Gambaran penggunaan zinc dan probiotik pada pasien diare pediatrik di Instalasi Rawat Inap Rumah Sakit X Kota Batam menunjukkan pemberian obat zinc rasional sebesar $67,21 \%$ dan tidak rasional sebesar $32,79 \%$, sementara pemberian probiotik rasional sebesar $59,01 \%$ dan tidak rasional sebesar $40,98 \%$.

\section{KETERBATASAN PENELITIAN}

Penelitian kami laksanakan dengan baik sesuai prosedur sehingga memperoleh hasil yang terbaik, akan tetapi masih terdapat keterbatasan penelitian karena penelitian ini bersifat retrospektif, setiap dokter anak yang berpraktek di Rumah Sakit X memiliki perbedaan peresepan pada kasus diare anak, serta jumlah sampel yang terbatas dan waktu penelitian yang singkat sehingga kurang mampu mengambarkan dengan baik.

\section{DAFTAR PUSTAKA}

Cipolle, R. J., Strand, L. M., Morley, P. C. 2015. Pharmaceutical Care Practice: The Patient - Centered Approach to Medication Management. McGraw-Hill, New York.

Hardiansyah, H., Arianti, B.I., Yulandari, V. 2018. Rasional Penggunaan Obat Pada Kasus Diare Balita Pasien BPJS Rawat Jalan RSUD Praya.Jurnal Kesehatan Qamarul Huda. 6(1): 1-6

Hikmawati, H. 2012. Hubungan perilaku ibu dalam penggunaan botol Susu dengan kejadian diare pada balita di ruang Delima RSUD Dr. Harjono Ponorogo. Skripsi. Program Studi D III Keperawatan, Fakultas IImu Kesehatan. Universitas Muhammadiyah Ponorogo.

Indriani, L., Fitriyanti, I., Azzikri, A., Amalul,., 2019. Penilaian Rasonalitas Pengobatan Diare Pada Balita di Puskesmas Bogor Utara Tahun 2016. Fitofarmaka vol.9, No.1, : 9-15

Iskandar, W.J, Sukardi. 2015. Manifestasi klinis diare akut pada anak di RSU Provinsi NTB Mataram serta korelasinya dengan derajat dehidrasi. Cermin Dunia Kedokteran, 42(8): 567-570.

Kementrian Kesehatan RI. 2011. Buletin Jendela Data dan Informasi Kesehatan Situasi Diare di Indonesia.

Kemenkes RI. 2011. Panduan Sosialisasi Tatalaksana Diare pada Balita. Jakarta: Direktorat Jenderal Pengendalian Penyakit dan Penyehatan Lingkungan

Profil Kesehatan Provinsi Kepulauan Riau. 2015. Dinas Kesehatan. Kepulauan Riau.

Sukardi, S., S. Yusran, L. Tina. 2016. FaktorFaktor yang Berhubungan dengan 
Kejadian Diare pada Balita Umur 6-59 Bulan di Wilayah Kerja Puskesmas Poasia Tahun 2016. Jurnal IImiah Mahasiswa Kesehata Masyarakat. 1(3): 1-12.

Sumawa, P. M. R., Wullur, A. C., Yamlean, P. V. Y., 2015. Evaluasi Kerasionalan Penggunaan Obat Antihipertensi Pada Pasien Hipertensi Rawat Inap Di Rsup Prof. Dr. R. D. Kandou Manado Periode Januari-Juni 2014 . Pharmacon, Jurnal IImiah Farmasi, Vol.4 No.3.

World Health Organization. 2009. Buku Saku: Pelayanan Kesehatan Anak di Rumah Sakit. Pedoman Bagi Rumah Sakit Rujukan Tingkat Pertama di Kabupaten/Kota. Jakarta: Kemenkes RI

World Gastroenterology Organisation. 2012. Acute Diarrhea in Adults and Children: A Global Perspective. 